\title{
Review
}

\section{Carl Schmitt's early legal-theoretical writings: Statute and judgment and the value of the state and the significance of the individual}

Lars Vinx and Samuel Garrett Zeitlin (Trans. and Eds.)

Cambridge University Press, Cambridge, 2021, xii + 260 pp.,

ISBN: 978-1108494489

Contemporary Political Theory (2023) 22, S34-S37. https://doi.org/10.1057/s41296022-00551-y; published online 8 February 2022

Lars Vinx and Samuel Zeitlin's opportune edition of Carl Schmitt's Statute and Judgement (1912) and The Value of the State and the Significance of the Individual (1914) provides not only a novel gaze on Schmitt's early thinking, but also a unique perspective on contemporary political and legal thought. A jurist by vocation and training, these early works exhibit a young Schmitt battling with the concepts that shape this later thought. Due to the subject and readership, the translators properly opted for a technical rather than a literary rendition, aiming for "terminological accuracy and consistency within the limits of readable English" (p. 157). The editors also provide a resourceful critical apparatus with hundreds of notes, as well as in-text German edition pagination which allows for easy comparison with the original.

In the informative introduction, the editors contextualize the texts and illuminate the continuities and discontinuities between the young and the mature Schmitt. Sovereignty already occupies a central role in these early works, helping to bridge the gap between law and state. Moreover, the strained relation between theology and politics, which shapes his political theology, obtains a new light with these writings. Contrariwise, over time he leaves behind his concerns with legal practice in order to focus on the political. Not only Schmitt scholars, but also any political theorist interested in the intersection between law, politics, and theology will find here an inexhaustible source to reflect on the precariousness and perils of the political.

In Statue and Judgement: An Investigation into the Problem of Legal Practice, Schmitt is concerned with legal practice, specifically the questions of when a judicial decision is correct. This problem emerges from the demand for a uniform practice. Usually, a decision is considered correct when it "conforms to statute," or, as Montesquieu said, when the judges are "the mouth that pronounces the words

(c) 2022 The Author(s), under exclusive licence to Springer Nature Limited. 1470-8914 Contemporary Political Theory Vol. 22, S1, S34-S37

www.palgrave.com/journals 
of the law" (p. 52). However, the statute contains gaps which need to be filled by the legal practice. Schmitt dismisses the prospects of originalism, because of the unfeasibility of recovering the real "will of the legislator" centuries later. Instead, he argues that "a decision is correct in the event that another judge would have decided in the same way" (p. 80). This definition assumes that the statutes participate in the present order of society, and that the habits, values, opinions, and cultural ideas of the people should be considered.

The principle of collegiality here is important because judges must communicate the reason for their decisions, and these justifications must be accepted by their colleagues on appeal (p. 105). In other words, legal practice "justifies itself through itself" (p. 115). This autochthonous nature of the legal practice seemingly places Schmitt's theory closer to Hans Kelsen's quest for methodological purity. However, contrary to Kelsen, who wants to remove all extra-legal aspects from the law, Schmitt defends the autonomy of legal science by subordinating these aspects to jurisprudence. It is the "ideal judge" who decides which cultural norms, moral opinions, sense of justice, weighing of interests, etc. is decisive in the concrete case. It is the practice that decides which extra-legal aspect will be used in the decision (p.126). The conformity with the statute will be preserved because, according to this formula, a judge will be hesitant to adjudicate against its wording.

Nevertheless, Schmitt deliberately avoids talking about the "stability of the law" (p. 139), as interpretations change over time. This formula can cope with "sudden upheavals," since during moments of "tempestuous development of the legal consciousness" (p. 139) judges will interpret the statutes based on the new extralegal situation. Therefore, the adjudication of the "ideal judge" will adapt itself to the new normal by coping with the exception. His goal is to affirm the independence of the judicial decision from the norm and its content. The law is what professional judges claim it to be in the concrete case, provided that the legal community accepts it.

In Political Theology (1922) and Dictatorship (1921), this independence becomes central, as sovereignty is identified with an independent political decision. Furthermore, in Nomos of the Earth (1950), Schmitt also praises early legal scholars for separating law from theology. For him, the decisive step in this separation was the transition from the theological system of thought, predicated on the church, to a juridical system centered on the state. In this new system, jurists replace theologians. Alberico Gentili coined the battle cry of jurists: Silente theologi in munere alieno! [Be silent theologian in alien territory!]. Afterward, it is evident that Schmitt is not only declaring the independence of legal science from theology and humanitarian moralism but also affirming the superiority of jurisprudence as the advocate of the political against moral and theological meddling.

The Value of the State and the Significance of the Individual, published two years later, investigates the tripartite complex: law, state, and the individual.

(C) 2022 The Author(s), under exclusive licence to Springer Nature Limited. 1470-8914 Contemporary S35 Political Theory Vol. 22, S1, S34-S37 
Clearly, the weakest side is the individual. Schmitt wants to go beyond the mere empirical individual to attain a new unity, a new spiritual bond. This bond emanates from the state and its grounded value, the realization of the law. Here law is independent and takes its value from itself and not from ethics. The latter is concerned with inner freedom while the former is related to external freedom. As jurists shall not mingle in the realm of Christ, the ethicists should at least recognize "the methodological autochthony of the realm of the world" (p. 171). The affirmation of the juridical over the theological recurs.

Initially, Schmitt investigates the relationship between law and power and recognizes two distinct opinions on this issue: (a) might makes right or (b) the irreconcilable antithesis between law and power. But both alternatives are unsatisfactory. To avoid these shortfalls, Schmitt argues that "the definition of the law begins where power becomes irrelevant" (p. 182). The problem is connecting these two realms while preserving the primacy of the law over power. This mediation is realized by the state.

However, the state is not the creator of the law; rather the law is the creator of the state. The significance of the state pertains to the realization of the value system entailed in the norm. So, "in the middle of this tripartition [law, state, and the individual] stands the state" (p. 197). The state is in the position of transitioning from the world of the norm "ought," to the empirical world "is." With this move, Schmitt avoids the antithesis between "ought" and "is" by leaving the enforceability of the law, which requires coercion, outside the realm of the norm. It is the world of being, the state, which uses power as a means to realize the law. However, the factual recognition of the normative element of the law does not come by itself, but rather from the members of the community, who recognize the necessity of giving the norm, as a system of values representative of the community, coercive means. Therefore, the primacy of the law is grounded, and the state becomes the "mediator of the law, whose meaning lies in realizing the law" (p. 207).

This statement appears to be in contradiction with his later theory of sovereignty. In Political Theology, the sovereign is characterized by the capacity to suspend the law. However, this aporia is only apparent, as the sovereign realizes a central function in The Value of the State, as abstract law must become positive statute by a sovereign decision. So the sovereign bridges the gap between the abstractness of the law and the concreteness of the state. To close this cleft, there is no gradual transition, but an act of sovereignty.

Regarding the individual, Schmitt openly adopts an anti-individualistic perspective by claiming that the true antithesis is between the law and the state. The state is not dependent on the individual, but rather, it is what makes the individual possible. Individuals become valuable only if they contribute, as instruments, for the realization of the law. As he writes, "The human being does not merit respect because it is a human being; it is the human being who is good 
and worthy of respect, rather, that merits respect" (p. 231). Here the idea of human dignity is reduced to its relationship with the community. The law, to be realized, requires a homogeneous mean, which presupposes the people to be good, but also excludes every heterogeneous element as enemy of the state. Those members who do not collaborate for the realization of the law are evil and are excluded from the community. Already in these early texts, the insights and aporias that mark Schmitt's thought are present. By affirming the superiority of the political against moral and theological meddling, Schmitt reduces everything to the political, and its friend and enemy distinction. Now, as in Schmitt's time, this hyper-politization leads to dire consequences.

Publisher's Note Springer Nature remains neutral with regard to jurisdictional claims in published maps and institutional affiliations.

Eduardo Schmidt Passos

University of Wisconsin-Madison, Madison, WI 53706, USA eduardo.schmidtpassos@wisc.edu 